\title{
Exegetical translation of the Qur'an: An action research on prospective Islamic teachers in Indonesia
}

\author{
Aam Abdussalam ${ }^{1 *}$, Tedi Supriyadi ${ }^{1}$, Udin Supriadi ${ }^{1}$ Aep Saepudin ${ }^{2}$, and \\ Muhamad Imam Pamungkas ${ }^{2}$ \\ ${ }^{1}$ Islamic Education Program, Faculty of Social Science Education, Universitas Pendidikan Indonesia, \\ Jalan Setiabudi no. 229, Bandung, West Java, Indonesia \\ ${ }^{2}$ Islamic Education Program, Universitas Islam Bandung, Jalan Tamansari No. 1, Bandung, \\ West Java, Indonesia
}

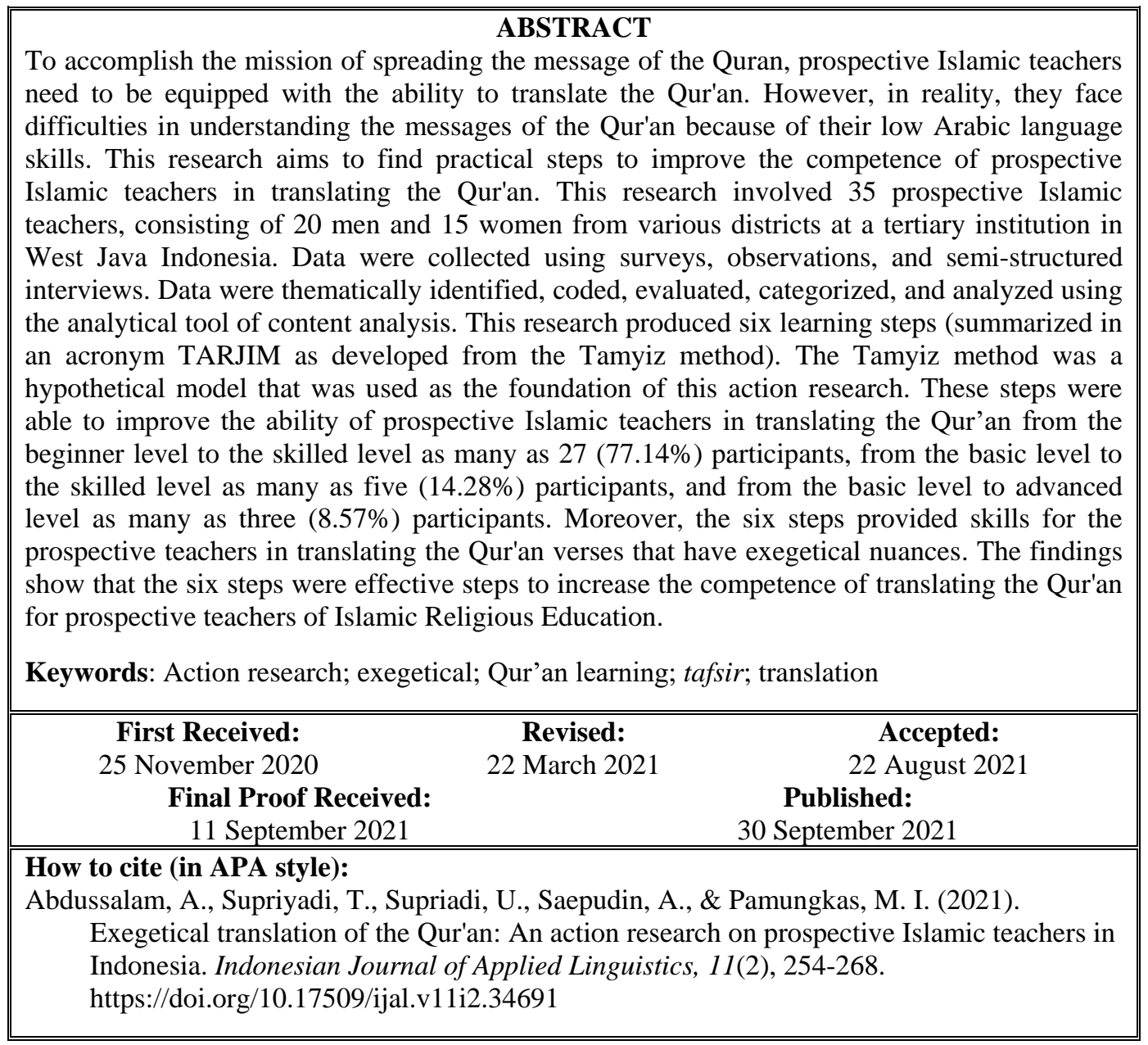

\section{INTRODUCTION}

Every Muslim has to spread the messages of the Qur'an to the best of their ability (Peachy, 2013). Since the messages of the Qur'an are in Arabic, they must be delivered in a form that everyone understands. This shows that Qur'an translation is important and mandatory. Conceptually, translation is delivering the meaning of a certain text from one language into another by using the closest possible equivalent (Mahasneh, 2018). According to Nida (1964, in Munday, 2016), formal equivalence focuses attention on the message itself, in both form and content, meanwhile, dynamic equivalence is where the relationship between receptor and message should be substantially the same as the one that existed between the original receptors and the message. Therefore, conveying the messages of the Qur'an must be accompanied by a good understanding of its contents (Supriyadi et al., 2019; Supriyadi et al., 2020). For prospective Islamic teachers, the competence to translate the Qur'an is a necessity because they have a strategic

\footnotetext{
*Corresponding Author

Email: aam86@upi.edu
} 
role and responsibility to convey the messages of the Qur'an to their students as a manifestation of the prophetic mission in spreading the Qur'an (Shihab, 1996). According to Hanafiah and Suhana (2009), students' learning model is not only related to the learning and teaching style but also interpreted as an approach to deal with changes in student behavior in an adaptive manner. Hence, it can be inferred that learning to translate Qur'an is hoped to generate expected manner.

One way to understand the Qur'an is by understanding the Arabic language (Ashim \& Rasyid, 2019; Ibrahim et al., 2015). This implies that prospective teachers need to have good Arabic language skills (Abdelnasser et al., 2014; Alqahtani \& Atwell, 2016; Dukes \& Buckwalter, 2010; Jimoh, 2018). Historically, the translation of the Qur'an has undergone a long dialectical process, from the question of the authority or legitimacy of the translator, the law of translating, and the presence of translations made by Orientalists. The process resulted in many differences among scholars in their response to the translation of the Qur'an in various regions (Baihaki, 2017). Some classical and contemporary scholars argue that translating the Qur'an is haram (forbidden), while others allow it (Chirzin, 2018). The prohibition of translating the Qur'an is based on the notion that translating the Qur'an into another language will reduce the miracles of the Qur'an. However, those who allow it has based it on a thought to convey the message of the Qur'an to all mankind from every level of society by determining the criteria and conditions that must be met in the process of translating the Qur'an (Al-Zarqani, 1995; Jalaluddin bin At-Tahir, 2008; Qassem, 2021).

However, in reality, prospective teachers tend to face difficulties in understanding the messages of the Qur'an because their Arabic language skills are minimal. The majority of these prospective teachers do not have a special educational background in the field of the Arabic language. As a result, they only rely on translations circulating on the internet without being accompanied by criticism regarding the credibility of the translators. This raises concerns about the potential growth of radicalism and even terrorism, which is allegedly caused by only relying on translation to understand the Qur'an. In specific, the literal translation of the Qur'an without proper interpretation might lead to justification of sinful behavior.

The Qur'an is the holy book of Muslims that has extraordinary literary height and serves as the main source of teaching for Muslims (Rohmana, 2019; Supriyadi et al., 2019) and is written in Arabic (Savaskan, 2019). Those who cannot understand Arabic cannot read the Qur'an in the original language. However, regardless of the conditions, the messages of the Qur'an as the holy book and God's revelation need to be communicated so that everyone can understand these messages. The translation of the Qur'an in various languages in the world including Indonesian is an effort to communicate and promote Qur'an (Baihaqi, 2019; Chirzin, 2018). In Indonesia, Qur'an is not only translated into the national language but is also translated into various local languages such as Sundanese or Javanese (Hanafi, 2011). According to As-Suyuti (2008), there are 15 branches of science that an exegete should master, namely: linguistics, al-Nahw (grammar), al-Sarf (morphology), alIshtiqāq (semantics), al-Ma'ān̄̄ (clear expression), alBayān (embellishment), al-Bad̄̄' (beautiful style), Qirā'āt (variation of readings), Ușul al-Dinn (theology), Usūl al-Fiqh (Principles of Islamic jurisprudence), 'ilm Asbāb al-Nuzūl (occasion of revelation), al-Naskh (abrogation), al-Fiqh (Islamic jurisprudence), al-Hadith (prophetic tradition), and 'ilm alMauhibah (the science beyond the power of human beings bestowed by God upon those who practice what they know). Moreover, Fee (2002) states that an exegete should have the ability to ask the right questions to get the intended meaning by questioning the content (what is said) and the context (why it is said). Fee (2002) further elaborates that the contextual questions should consider the historical and literary contexts, while the questions of content should emphasize textual criticism, lexical data, grammatical data, and historical-cultural background.

According to Stolze (2012), semantic in a text provide context-specific strategies to present the meaning of the text. Moreover, semantic translation attempts to render, as closely as the semantic and syntactic structures of the second language allow, the exact contextual meaning of the original (AsSafi, 2011). Therefore, Abdelaal and Md Rashid (2015) stated that the only acceptable translation is exegetical-a translation based on commentary books. Concerning this, Baker (2011) states that the acceptance of text, including translation work, is not based on its correspondence with a certain situation, but its relation with the interlocutor.

Furthermore, the translation method also needs to be mastered because it greatly affects the results of the translation of the text as a whole. Newmark, (1988, p. 45) grouped translation methods into two big groups. The four first methods emphasize the source text, namely word-for-word translation, literal translation, faithful translation, and semantic translation; and the four-second methods focus on the target language, namely: adaptation, free translation, idiomatic translation, and communicative translation.

In addition to Arabic, a translator should also have insight related to Qur'an interpretations to understand the messages of the Qur'an. Without having excellent knowledge of the interpretive books, a translator will undoubtedly fail in translating the Qur'an (Abdelaal \& Md Rashid, 
2015). Translation only explains the meaning of the verses into the language of people who have not mastered Arabic (Baihaki, 2017). Translators have their style of language. However, what needs to be maintained is the purpose of a verse. The meaning of the verse must be clearly expressed in translation (Bakry, 1983). With exegetical analysis, this goal can be achieved. Chang (2004) affirms that exegetical papers must seek to discover and explain what the text meant for the original author and his readers. After an exegetical study, the student must offer the best understanding of what the biblical author intended to communicate to the first readers

Concerning understanding of the exegetical text, there are two crucial implications that the exegete should comprehend, namely the ability to communicate a particular historical situation with God's own intention for that situation and the effort to comprehend the scripture in the light of grammar principle and historical facts (Piper, 2013). On its most basic level, exegesis consists of expounding linguistic meaning in its appropriate historical context (Dahan, 2015; Matin \& Alwi, 2020; Ocker, 1999). Therefore, the exegete (mufassir) should portray the quality of an ethical person imbued with perfect intelligence (Pregill, 2020; Qadafy, 2019) They should also have good intentions, morality, willingness, credibility, tawaddu', nobleness, and the courage to speak the truth, polite gestures, clear speech, a willingness to prioritize those who are more entitled to interpret the Qur'an, and good preparation and delivery (Hasan, 1984).

Exegesis is the act of explaining a text, which is done through careful analysis of the text based on a careful and objective analysis (Aichele \& Phillips, 1995; Pepinsky, 1982; Williams, 1973). In specific, Porter and Clarke (1997) defined exegesis in written text as reading out the text meaning. In carrying out the analysis, it should discover the true meaning of the text by respecting its grammar, namely the morphology, syntax, and setting. This process involves observation, interpretation, and application stages. First, the observation is done to see what the text says by looking for clues, understanding the context, and examining the text based on the terms, structure, literary form, atmosphere, and suggested markers. Second, the interpretation is done to know what the text means by consulting to available helpful tools (such as commentaries or encyclopedia), solving which interpretation best fits the passage, and evaluating questions answered, and the meaning of the passage understood, Third, application stage is to know how the truth behind the text relates to the readers (Pepinsky, 1982; Williams, 1973). Furthermore, the exegetical paper aims at presenting the most plausible, wellsupported translation, explanation, and interpretation of a given passage, argued by means of rigorous research, critical judgment, and accepted methods of biblical exegesis (Iqbal \& Ja'far, 2019; Piper, 2013).

If we adhere to the paradigm that the Qur'an cannot be translated, only the Arabs will understand the contents of the Qur'an (Baihaki, 2017). For people who do not understand Arabic, practicing the values of the Qur'an and knowing the meaning of a verse can at least be done through translation works (Ali et al., 2012; Halimah, 2014; Imamuddin et al., 2020; Raharjo et al., 2018). However, the depth of understanding the Qur'an of the people who already have Arabic language skills will certainly be different from people who do not have Arabic language skills. Therefore, in the Islamic tradition, learning Arabic is a necessity because the life of a Muslim in various aspects, especially in ritual worship, cannot be separated from the use of Arabic language, more specifically because Arabic is the language of the Qur'an (Baihaki, 2017; Baihaqi, 2019; Hanafi, 2011).

There have been several studies on the exegesis of the Qur'an. Qadafy (2019) conducted a study that analyzed two scholarly tafsir books circulating throughout modern Indonesia. He found out that these two books are concerned with attracting the attention of lay readers and, accordingly, endeavour to present their information in a comprehensible and accessible manner. In terms of content, the two books limit their discussion to the apparent (zāhir) meaning of the Qur'an, an understanding that depends on a reader's knowledge of Arabic; one might call it an immediate understanding of the text. Woodward (1993) conducted a study that is primarily concerned with the ways hadith translations are used to legitimize cooperation between the conservative Muslim organization Nahdlatul Ulama (hereafter NU) and the secular government and as critiques of modernism, radical activist rhetoric, and of kejawen (Javanese) Islam, which stresses local formulations of Sufism while neglecting the ritual requirements of Islamic law. Ikhwan (2015) focuses on examining Quraish Shibab's exegetical thoughts and articulation of religion in the modern and pluralistic context of Indonesia. His research discovered the role of Quraish Shihab, a popular cleric in Indonesia in re-centring the position of the Qur'an as the guidance to address current exigencies of Indonesian Muslim society. Peachy (2013) studied the English translation of the Qur'an and suggested the importance of the four questions in translating the Qur'an, namely: Why was the Qur'an translated? Who translated the Qur'an? Whom is the translation for? How is the Qur'an translated? These four questions are important guides for the translators because they are responsible for making many difficult and crucial decisions that will affect the accuracy, clarity, and acceptability of their work. Meanwhile, Abdelaal and Md Rashid (2015) investigated the semantic loss in the translation of 
Surah al-Waqi'ah by Abdullah Yusuf Ali. They suggested that there were semantic weaknesses in the English translation of Surah al-Waqi'ah. Translators sometimes choose incorrect words in their semantic field.

In the context of Indonesia, there have been at least two studies on Qur'an translation done. Afan (2014) reported that an Islamic organization in Indonesia, the Indonesian Mujahidin Council (MMI, Majelis Mujahidin Indonesia), claimed that there are many errors in the Qur'an translation published by the Ministry of Religion of the Republic of Indonesia (Kemenag RI). Ahmadi (2015) and Chirzin (2018) support these findings by comparing the Qur'an translation produced by Kemenag RI and that of Muhammad Thalib. Thalib found that the 2010 edition of Qur'an translation by Kemenag RI contains 3,400 errors. For example, the translation of Al-Baqarah (verse 191) used the phrases of "kill them", which can lead to partial understanding that can make people unable to contextualize their understanding in a concrete situation. He claimed that the Kemenag RI Team used harfiyah (textual) approach that was forbidden by scholars. Thus, Thalib formulated the Al-Qur'an Tarjamah Tafsiriyah as a correction to the translation work of the Kemenag RI Team. Although the accusation was denied by Kemenag RI, it indicates that the product of the translation is debatable and becomes an interesting discourse to reveal. Chirzin (2018), however, found that the difference between the two translations was only on their respective emphasis points, in which the translation of the Kemenag RI was oriented towards faithful language translation, while Thalib's translation was oriented towards tafsiriyah translation with its advantages and disadvantages

Researchers' interest above indicates that the study of Qur'an translation is quite in demand. However, based on literature in reputable journals taken from Scopus data for the period 2010-2019, research related to the Qur'an translation is limited to content analysis that examines translated products by comparing one translation result with another. There has been no research in the context of producing Qur'an translators. Therefore, this research is focused on how to improve the Qur'an translation competence of prospective Islamic teachers by implementing an exegetic approach in Qur'an translation to address the limitations of harfiyah and tafsiriyah approaches. It aims at finding solutions to address low Qur'an translation competency possessed by prospective Islamic teachers. In specific, the research activities were done in the following stages: (1) exploring research participants' ability to translate Qur'an; (2) developing strategic steps to address the problem found; and (3) evaluating the results.

\section{METHOD \\ Research design}

Action research (AR) as developed by McTaggart (1996) has been used as the method of the research. Theoretically and politically, AR has always been used as a basis for exploring an issue related to critical pedagogy (Gibbs et al., 2017; Supriyadi \& Julia, 2019). With this AR design, solutions to problems related to the ability of prospective teachers in translating the Qur'an are sought.

One of the characteristics of AR is the collaborations with other parties (Bruce et al., 2011; Creswell, 2002; Ferguson-Patrick, 2007; Jaipal \& Figg, 2011; Leeman et al., 2018; Somekh, 2010). On this base, four people, namely an expert of Qur'an interpretation, two lecturers with expertise in the Arabic language, and a lecturer with expertise on Islamic Religious Education were made the collaborators to this research. A study prior to the research was conducted to determine the indicators of success in this research. The indicators were based on the need for prospective Islamic teachers to actualize their knowledge later in schools both at the primary and secondary levels. The success indicators of prospective Islamic teachers in achieving competence in translating the Qur'an are presented in Table 1.

\section{Research site and participants}

This research was conducted at one of the universities in Indonesia that produce educators and education personnel in the field of Islamic religious education. These research participants were 35 university students consisting of 20 male students and 15 female students who were taking Ulum alQur'an (science of Qur'an) subject in their third semester. They were 19 to 20 years old prospective teachers of Islamic religious education coming from various regions in West Java province, Indonesia. They were high school graduates and had minimal Arabic skills.

\section{Data collection}

Data were collected using surveys, observations, and semi-structured interviews. The survey was carried out using the Google Document with the Likert and Guttman scales. The research procedure was carried out in three stages. The first stage was exploring problems related to the participants' ability to translate the Qur'an. The second stage was compiling strategic steps to improve the ability of the participants in translating the Qur'an based on the problems identified. The third stage was evaluating all actions given and matching the results of the previous stages by referring to the predetermined indicators. In each stage, reflections were made to improve and to take needed actions in the next step 


\section{Data analysis}

Data collected from the survey, observations, and semi-structured interviews were thematically identified, coded and evaluated, categorized, and analyzed using the analytical tool of content analysis offered by Krippendorff (2018). The analysis was discussed and examined by the collaborating experts involved in this research.

Table 1

Indicators of Competency Achievement in Translating the Qur'an for Prospective PAI Teachers

\begin{tabular}{|c|c|c|c|}
\hline No & Level & Indicator & Assessment \\
\hline 1. & Beginner & $\begin{array}{l}\text { 1. The recitation of the Qur'an is good and correct. } \\
\text { 2. Can mention the meaning of only a few words contained in a } \\
\text { verse of the Qur'an. }\end{array}$ & Poor \\
\hline 2. & Basic & $\begin{array}{l}\text { 3. Can distinguish isim (noun), fi'il (verb) and letters used in the } \\
\text { composition of a verse of the Qur'an } \\
\text { 4. Can distinguish the sentence structure of Ismiyah fi'liyah used } \\
\text { in a verse of the Qur'an. } \\
\text { 5. Can say and look up the meaning of each word in a verse of the } \\
\text { Qur'an with the help of a dictionary and memorize vocabulary } \\
\text { in the verse that is read. }\end{array}$ & Fair \\
\hline 3. & Skilled & $\begin{array}{l}\text { 6. Can mention the position of words in each sentence contained } \\
\text { in a verse of the Qur'an and how to translate them into } \\
\text { Indonesian. } \\
\text { 7. Can mention the background of the descent (asbabun nuzul) of } \\
\text { a verse or surah in the Qur'an. } \\
\text { 8. Can mention the meaning of each word in a verse of the Qur'an }\end{array}$ & Good \\
\hline 4. & Advanced & $\begin{array}{l}\text { 9. Can mention the meaning of every word in a verse or surah of } \\
\text { the Qur'an lexically and grammatically, and can also choose } \\
\text { the appropriate diction in translating the verse } \\
\text { 10. Can deliver the purpose of a verse based on references of tafsir } \\
\text { (interpretation) }\end{array}$ & Excellent \\
\hline
\end{tabular}

\section{FINDINGS AND DISCUSSION}

\section{Analysis of pre-action}

The 35 participants were given several tests to classify them based on their level of ability. The tests were written tests to measure the participants' Arabic dictation skills and oral tests to measure their language skills, especially the vocabulary. They analyzed the sentence structure in the editorial of a verse of the Qur'an, the types of words used, and the meaning of each word in a verse. The test also measured other knowledge related to the Qur'an such as asbabun nuzul and insight into tafsir. Surah Al-Baqarah was used as the test tool chosen because $75 \%$ of the vocabulary in the Qur'an was contained in it (Abaza, 2010; Himam \& Raswan, 2017; Supiana et al., 2018). To facilitate the mastery of vocabulary, the participants memorized the words by using the song rhythm. Intrinsically, singing a song can help motivate, maintain focus, and be quite enjoyable for students of all ages (Good, et al., 2015). In addition, songs can embody and summarize memories (Funabiki \& Konishi, 2003; Harvey, 2010). The verses used as test instruments are those having asbabun nuzul, which is based on the verse division in Figure 4. The test results can be seen in the following table.

Table 2 shows that the majority of the participants' ability to translate the Qur'an is in the poor category. Twenty-seven $(77.14 \%)$ participants showed poor assessment indicators. This means that their ability was at the beginner level. Eight
$(22.86 \%)$ participants were in quite good assessment indicators. This means that their ability was at the basic level.

Table 2

Results of Initial Ability Test in Qur'an Translation

\begin{tabular}{lcc}
\hline Level & Number & Percentage \\
\hline Beginner & 27 & $77.14 \%$ \\
Basic & 8 & $22.86 \%$ \\
Skilled & & \\
Advanced & & \\
\hline Total & 35 & $100 \%$ \\
\hline
\end{tabular}

The test results indicated that the participants' Arabic language skills needed to be improved through a number of intensive, brief, and effective learning experiences given the time allocated in lectures was very limited. Increasing the Arabic language skills is important because Arabic is a supporting knowledge in translating the Qur'an. Moreover, the ability to speak Arabic also has a positive influence on one's religious behavior (Mustofa, 2019).

In addition to Arabic, the participants' insights and experiences related to other supporting knowledge such as tafsir and asbabun nuzul needed to be strengthened through a number of literacy experiences of tafsir and asbabun nuzul. This was important because without insight of asbabun nuzul, it was difficult to understand the context of a verse or surah in the Qur'an. The translation that misses its historical context is caused by a person's lack of 
insight regarding asbabun nuzul (Alifuddin, 2012; Bakri, 2016; Rippin, 1988). Likewise, without interpretive insight, the Qur'an translation will fail (Abdelaal \& Md Rashid , 2015).

Even though the participants' level of ability is at the beginner level, they already had the most fundamental capital to start understanding the Qur'an: the ability to read the Qur'an well. The ability to read is a must to understand and actualize the messages of the Qur'an in life (Alhamuddin et al., 2018; Hakim, 2019; Rahman et al., 2017; Supriyadi et al., 2020). In addition to reading, motivational capital is also very important because underachievement is not caused by a lack of ability, but by the lack of motivation to learn.

Regarding the participants' motivation in improving the competence of translating the Qur'an, a survey was conducted. The survey results are presented in Table 3.

Table 3

Motivation of Prospective Teachers Regarding the Competence of Translating the Qur'an

\begin{tabular}{|c|c|c|c|c|c|}
\hline Statement & SD & D & RD & $\mathbf{A}$ & SA \\
\hline $\begin{array}{l}\text { 1. Prospective Islamic Education teachers must have the ability to } \\
\text { translate the Qur'an. }\end{array}$ & & & & 27 & 8 \\
\hline $\begin{array}{l}\text { 2. To find out the translation of the Qur'an, I only need to look at } \\
\text { existing translation results. }\end{array}$ & 16 & 19 & & & \\
\hline $\begin{array}{l}\text { 3. To be able to translate the Qur'an, I need to have good Arabic } \\
\text { language skills. }\end{array}$ & & & & 11 & 24 \\
\hline $\begin{array}{l}\text { 4. To be able to translate the Qur'an, I need to have insights of } \\
\text { asbabun nuzul and tafsir of the Qur'an. }\end{array}$ & & & & 5 & 30 \\
\hline
\end{tabular}

Note: SD: Strongly Disagree D: Disagree RD: Rather Disagree $\quad$ A:Agree $\quad$ SA: Strongly Agree

Table 3 shows the participants' high motivation and awareness of the importance as prospective teachers of Islamic Education to have the ability to translate the Qur'an and the importance of other supporting knowledge that must be possessed to achieve competency in translating the Qur'an.

\section{Implementation of action}

Based on the results of the analysis, this research offered six steps as an action to improve competence in translating the Qur'an for prospective Islamic Education teachers. The six steps are explained as follows.

\section{Arabic language training with the Tamyiz Method}

The success of learning depends on the method used and the material presented (Sani, 2013). To improve Arabic language skills, the Tamyiz method was used. The Tamyiz method was developed by Zaunal Fatin from the Bayt Tamyiz Islamic boarding school, which offers mastery of Arabic within 100 hours (Himam \& Raswan, 2017). Many researchers in Indonesia conducted studies on Tamyiz method and have proven its effectiveness (el Fauzy, 2018; Farhan, 2017; Mukroji, 2014).

The material presented in the Tamyiz method is not much different from the Arabic language material in general, namely Nahwu (rules that can recognize Arabic both in terms of i'rab and bina') and Sharaf. Through the Nahwu, the participants were provided with concepts related to the division of words in Arabic such as isim, fiil and huruf used in the editorial of a verse, distinguishing fi'liyah and ismiyah of sentences, and the position of a word in a sentence. Examples of nahwu material in the Tamyiz method are as shown in Figure 1. Through the Sharaf, the participants were equipped with the ability to analyze a word-formation and the origin of words in the editorial of the Qur'an verse. The ability to search for the origin of words made it easier for the participants to look for the meaning of a word in Arabic dictionaries. The difference between the Tamyiz method and other methods is the ability of Tamyiz method to reconstruct complex nahwu and sharaf materials into simple ones and can be reached in a relatively short time to achieve Arabic language skills, which took 100 hours (Farhan, 2017). In addition, Tamyiz has a vocabulary compiled in the Kawkaban dictionary (Abaza, 2010).

The implementation of the 100 hours program using the Tamyiz method was adjusted to the time allocation presented in the lecture system. The number of credits for the Arabic course each week is three credits (510 minutes), which consists of 150 minutes for face-to-face sessions, 180 minutes for structured assignments, and 180 minutes for independent assignments based on initiative. The Tamyiz method spent approximately 14 weeks with 12 face-to-face sessions and 2 comprehensive evaluations. Based on several tests given and a comparison of pretest and posttest results, the Arabic language skills of prospective Islamic teachers are described in Table 4.

Table 4 shows an increase in the participants' Arabic language skills with an average increase of $84.28 \%$. At this stage, the participants showed the ability to translate the Qur'an in Surah Al-Baqarah. 
Figure 1

An example of materials in the Tamyiz Method

AL-OURAN TRANSLATION TAMYIZ METHOD

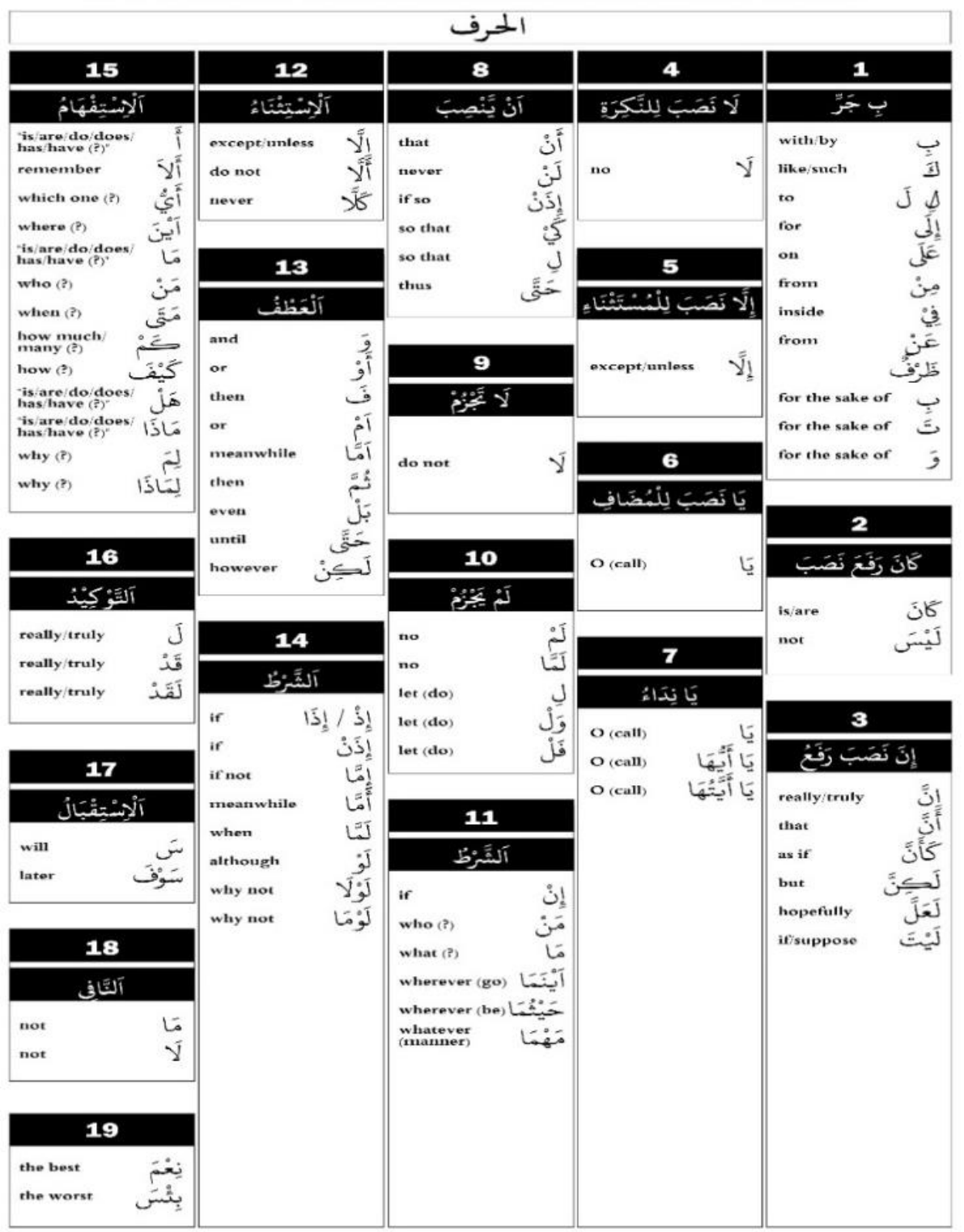

Table 4

Results of the Arabic Language Intensive Training with the Tamyiz Method

\begin{tabular}{|c|c|c|c|c|c|c|}
\hline \multirow{2}{*}{ Arabic Language Skills } & \multicolumn{2}{|c|}{ Pretest } & \multicolumn{2}{|c|}{ Posttest } & \multicolumn{2}{|c|}{ Improvement } \\
\hline & Total & $\%$ & Total & $\%$ & Total & $\%$ \\
\hline $\begin{array}{l}\text { Able to distinguish types of Isim, Fiil and Huruf in each } \\
\text { verse contained in Surah Al-Baqarah }\end{array}$ & 5 & 14.28 & 35 & 100 & 30 & 85.71 \\
\hline $\begin{array}{l}\text { Able to distinguish the number of Ismiyah and Fi'liyah } \\
\text { used in every verse in Surah Al-Baqarah }\end{array}$ & 3 & 8.57 & 32 & 91.42 & 29 & 82.85 \\
\hline $\begin{array}{l}\text { Able to explain I'rob of Sentence in every verse in Surah } \\
\text { Al-Baqarah }\end{array}$ & 2 & 5.71 & 29 & 82.85 & 27 & 77.14 \\
\hline Able to translate Surah Al-Baqarah & 2 & 5.71 & 34 & 97.14 & 32 & 91.42 \\
\hline Average Arabic Language Ability & 4.25 & 12.14 & 32.5 & 92.86 & 29.5 & $84.28 \%$ \\
\hline
\end{tabular}

However, their ability was limited to textual translating or harfiyah, while the Qur'an cannot be translated using the harfiyah approach alone(Abdelaal \& Md Rashid, 2015). With harfiyah translation, there is a potential loss of the semantic meaning of the Qur'an due to the inaccuracy of the selected vocabulary, which can cause a shift in meaning (Abdelaal \& Md Rashid, 2015). The lack of similarities in several cultural words between the Qur'an and Indonesian requires a translator not only to have great skills in both languages but also great knowledge of literature and the culture in which the 
Qur'an was revealed (Peachy, 2013). As a solution to this, the collaboration team referred Abdelaal and Md Rashid's (2015) concept of exegetical translation as a style based on tafsir books so that the direction of the participants' competence in translating the Qur'an was focused on exegetical translation.

\section{Text analysis and collecting meaning of words}

To minimize the inaccuracy in choosing the meaning of words, the participants needed to have a deeper insight into the meaning of Arabic vocabulary. Therefore, this step was focused on enriching the vocabulary of the meaning of each Qur'anic word. The participants were instructed to analyze, collect, and compile other possible word meanings contained in the Kawkaban dictionary, which was the initial guideline and reference in translating the Qur'an. This stage was important so that the participant's knowledge regarding the meaning of a word in the Qur'an does not only rely on the meaning contained in the dictionary. An Arabic word can be translated into several words in Indonesian. For example, the verb ضَرَبَ can be translated into memukul (to hit), membuat (to make), or menjadikan (to become). Another example is Arabic letter J that can mean untuk (to/for), karena (because) and milik (to belong) in Indonesian.

Equipped with sharaf knowledge obtained from the first stage, the participants searched for other meanings or equivalent words related to a lafadz (pronunciation) in the Qur'an in the Kawkaban dictionary or in representative ArabicIndonesian dictionaries and reliable examples such as Warson's (1997) al-Munawir dictionary, Ali and Muhdlor's (1996) Contemporary Dictionary, and Bisri's (1999) Al-Bisri Dictionary. All 35 participants in this research succeeded in making an inventory and enriching the meaning of every word in the Kawkaban dictionary, on average of 1-3 other meanings. Enriching the Kawkaban dictionary was hoped to help them in choosing the right words in translating the Qur'an. Diction in translating the Qur'an is a necessity because the choices of the right words and usage must be able to represent the idea of a verse so that certain effects are obtained as desired by the verse itself.

\section{Tafsir Ibnu Katsir (TIK)-based reading of Tafsir and Asbabun Nuzul}

Regarding the possibility that a lafadz in the Qur'an has multiple meanings, then, the next problem was deciding which meaning was the most appropriate to be used in translating a lafadz or a verse. This required understanding of the context of the verse so that the translation did not become obscure or was only based on the translator's subjectivity. Therefore, a translator must have understanding of the sciences of the Qur'an in translating it. Two of these sciences are tafsir and asbabun nuzul, which will help the translator grasp the context of a verse. By reading tafsir and asbabun nuzul, the participants could at least understand and classify the content of verses into three categories, namely verses that contain credal (aqidah), Islamic law (syariah), or moral (akhlak) aspects, because the Qur'an as the source of Islamic teachings contains those three aspects of teachings (Majid, 1995).

To make it easier for them to study the tafsir and asbabun nuzul, an Android-based information technology was used as a learning medium in this step. The participants were instructed to install the TIK application developed by Muslim Media on their smartphones. The application was chosen because (1) everyone has a smartphone; (2) the application has representative features for tafsir learning, such as (a) complete presentation of the Qur'an (30 juz and $114 \mathrm{surah} / \mathrm{chapter}$ ), (b) good translation of verses and interpretations, (c) a collection of four tafsir works of credible scholars (Tafsir Ibnu Katsir, Tafsir Jalalain, Tafsir alMuyassar, and the tafsir issued by The Ministry of Religious Affairs of Republic Indonesia), which have become references in almost all Islamic boarding schools in Indonesia; d) an explanation of the background to the passage of the verse or surah (asbabun nuzul), (e) a feature for studying the hadiths (a collection of traditions containing sayings of the Prophet Muhammad) that are relevant to a verse, (f) a search engine feature to search for translations of the Qur'an based on the desired keywords, (g) thematic verse features, and so on; and (3) in terms of costs, the TIK application is more efficient than buying the printed versions of the four books. Figures 2 and 3 show the application's display and description of the features on Google Play.

\section{Figure 2}

Display of TIK Application on Google Play

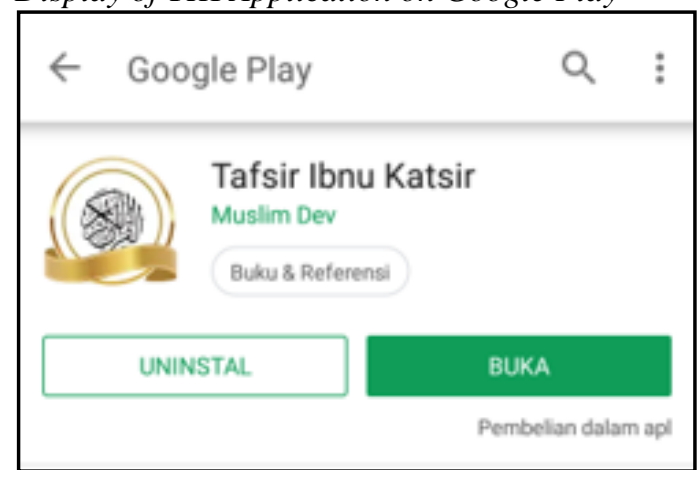

The instructional steps in the learning process started from the guide to install, to understand the features, and to do the tafsir learning process. The material for the tafsir was focused on examining Surah Al-Baqarah from the perspective of the mufasir (expert of Qur'an interpretation) in the application. At the end of the learning activity, the participants perceptions related to tafsir learning using TIK application were surveyed. The survey results can be seen in Table 5 . 
Figure 3

Features in Tafsir Ibnu Katsir Application

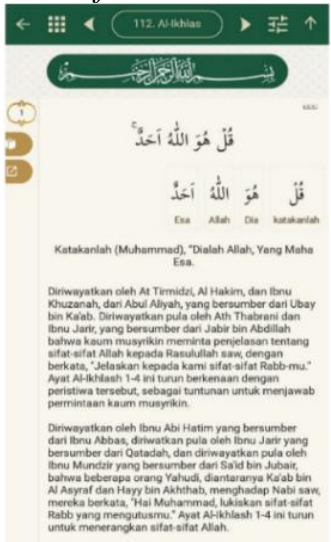

Interface of Asbabun Nuzul

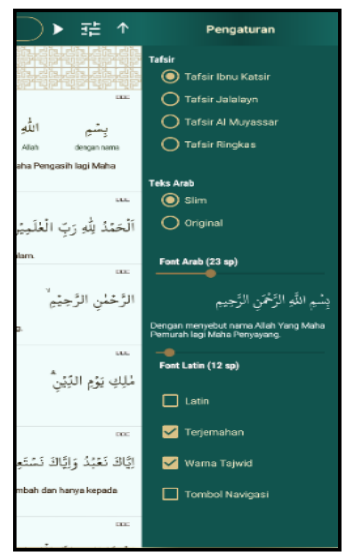

Tafsir Selection Menu

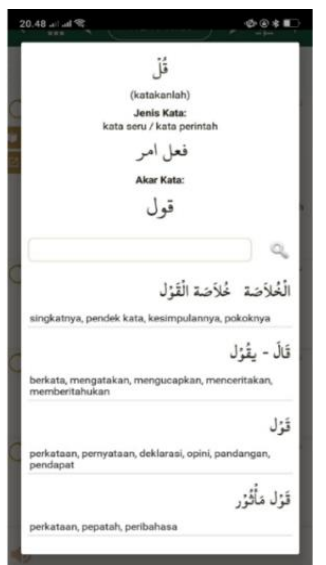

Explanation of Word Meaning

Table 5

Perceptions of the Research Participants of TIK-based Interpretation Learning

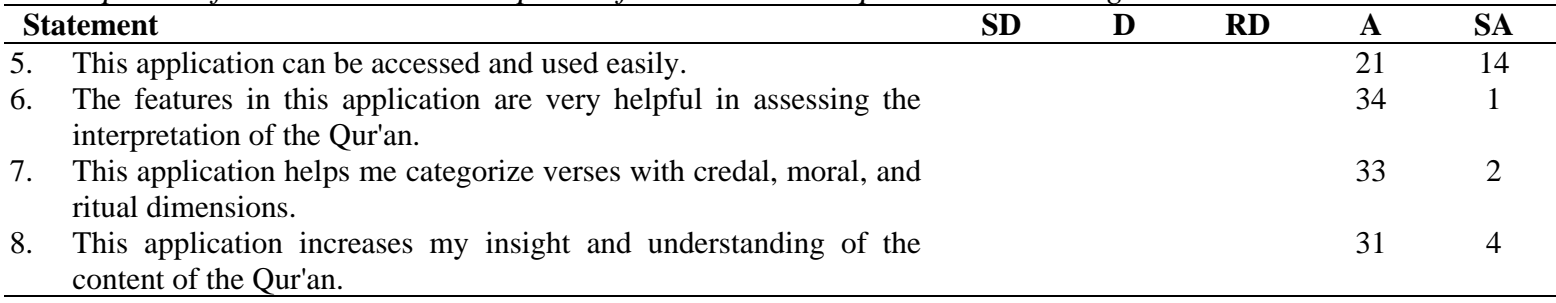

Note: SD: Strongly Disagree D: Disagree RD: Rather Disagree $\quad$ A:Agree $\quad$ SA: Strongly Agree

Table 5 shows that all participants responded positively to the TIK application as a learning medium in studying the tafsir of the Qur'an. The participants perceived that the application was easily accessible and practical. They agreed that the features in the application helped them in studying the tafsir of the Qur'an, helped them classify the verses of the Qur'an, and increased their insight and understanding of the contents of the Qur'an.

To support the results of this survey, the participants were tested to mention the views of the mufasir regarding the content of verses 1-20 in Surah Al-Baqarah through this application. The test results are presented in Table 6:

Table 6

Test Results of TIK-based Tafsir Learning

\begin{tabular}{|c|c|c|}
\hline Assessment Indicator & Total & Percentage \\
\hline 9. Able to mention asbabun nuzul of a verse & 33 & $94.28 \%$ \\
\hline 10. Able to mention relevant hadiths related to a verse & 34 & $97.14 \%$ \\
\hline 11. Able to mention the topic of a verse (topic of aqidah, syariah, or akhlak) & 35 & $100.00 \%$ \\
\hline 12. Able to express the content of a verse based on the explanation of the mufasir & 33 & $94.22 \%$ \\
\hline
\end{tabular}

Table 6 shows the congruity between the participants' statements regarding tafsir learning with their abilities based on the test results. As the table shows, all of the participants were able to mention the topic of a verse and classify the verses into the categories. This implies that the participants already had tafsir literacy skills even though it was still limited to the four tafsir works.

\section{Joint assessment on translated works}

Equipped with the insights and skills they already had in the previous stages, the participants were then divided into seven groups to review eight translated works of the Qur'an published in Indonesia. Each group was instructed to review three works and compare one translation with another. Henceforth, they provided feedback and assessment.

The focus of the comparison was limited to Surah Al- Baqarah. They investigated the diction and style of translation used by each translator. Based on their review and assessment, the participants reported that six $(75 \%)$ works tended to be harfiyah or textual translations and two works (25\%) tended to be tafsiriyah translations. This implied that the tendency for the Qur'an translation in circulation was dominated by the literal translation style. Newmark (1981) states that literal translation is the best approach in both semantic and communicative translation. However, in translating Qur'an, this literal translation should then be either combined with exegetical translation or not against 
its principles because as Abdelaal and Md Rashid (2015) stated, the only acceptable translation is exegetical translation-a translation based on commentary books.

\section{Improvement}

As a follow-up to the participants' findings regarding the translation works circulating in Indonesia and as a form of their contribution to the translation of the Qur'an, the participants were directed to compile translated works based on books of tafsir. As stated by Abdelaal and Md Rashid (2015), an acceptable translation is a translation based on the books of the mufasir. To facilitate them, the participants were given a guide in the form of mapping of verses in Surah Al- Baqarah that was adopted from a fan page Efham Aya as in Figure 4.

\section{Figure 4}

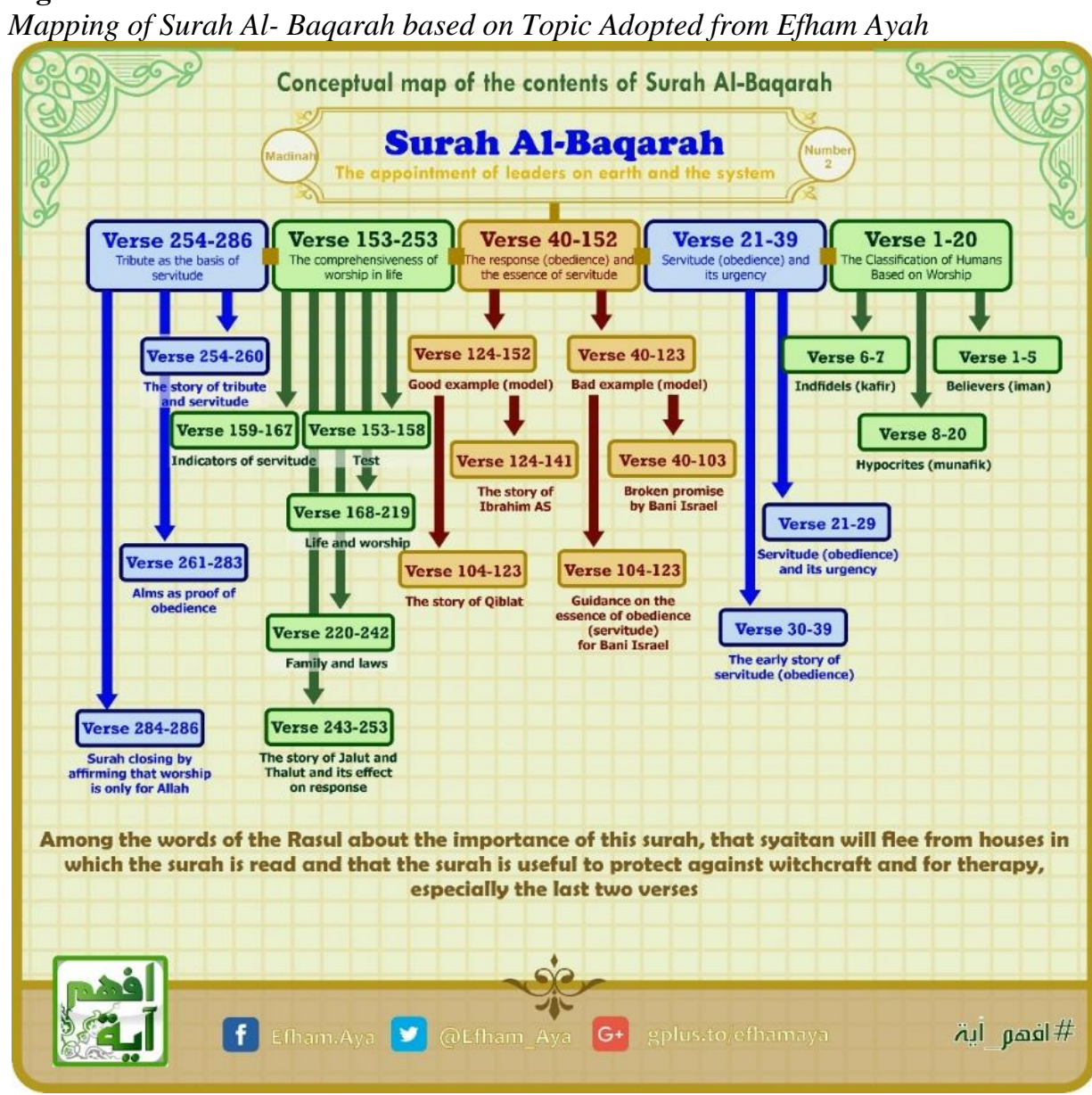

Source: modified from https://www.facebook.com/efham.aya/?ref=page internal

The above concept map guided the participants in translating the Qur'an so that the translation practice did not deviate from the context of the verse. The verse mapping was divided into five groups of verses, namely verses 1-20 related to human in worshiping God with all its characteristics, verses 21-39 related to the importance of worship for humans, verses 40-152 related to the nature of worship, verses 153-253 related to the scope of worship in life, and verses 254-286 related to the principles of worship.

\section{The practice of translating the Qur'an with the exegetical style}

This was the final stage in the learning process. The participants were given a project to translate Surah
Al-Baqarah based on five groups of verses as explained in the previous stage. They were instructed to describe the I'rab (the changing of the word endings due to the addition of specific elements to find out whether they are actual or supposed) of each verse and the meaning of each $l a f a d z$ and to provide an explanation of the meaning of a verse based on the tafsir references they had read. The following table summarizes the findings related to the participants' ability to translate the Qur'an. The majority is in the good category and the rest are in the very good category. The number of participants included in the good category was 32 $(91.43 \%)$ participants, while three $(8.57 \%)$ participants were included in the very good category. 
Table 7

Representation of Participants' Ability in Translating the Qur'an

\begin{tabular}{|c|c|c|c|c|}
\hline Ability & $\begin{array}{cc}\text { Poor } & \begin{array}{c}\text { Rather } \\
\text { Poor }\end{array}\end{array}$ & Fair & Good & Very good \\
\hline 13. Translating every word & & & 32 & 3 \\
\hline 14. Explaining the $I^{\prime} r a b$ in each verse & & & 31 & 4 \\
\hline 15. Providing an explanation of asbabun nuzul & & & 32 & 3 \\
\hline $\begin{array}{l}\text { 16. Providing an explanation of the intent based on } \\
\text { interpretation }\end{array}$ & & & 33 & 2 \\
\hline Average & & & 32 & 3 \\
\hline
\end{tabular}

Evaluation results of the action

The findings in each learning stage represented an increase in the ability of the prospective teachers in translating the Qur'an. By referring to the indicators set in Table 1 and comparing the results of the preaction and post-action stages, this increase is illustrated as in Figure 5.

\section{Figure 5}

Representation of the Increase of the Qur'an Translation Ability

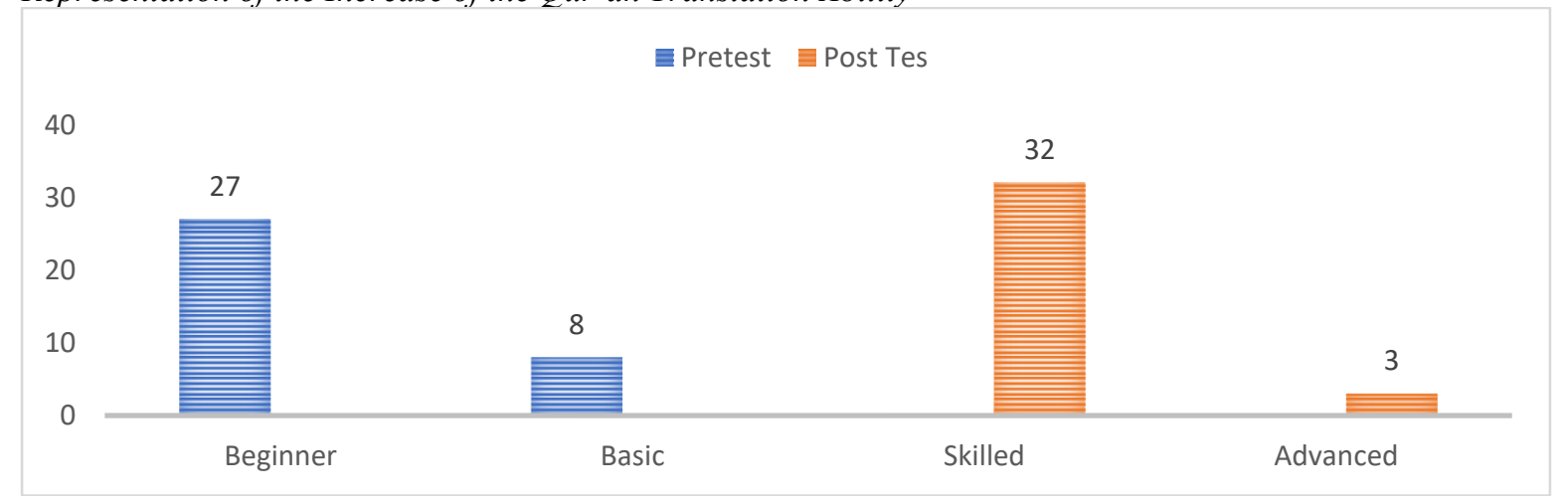

The figure shows that by implementing the six steps of action, the participants' ability increased. As for the form of this increase, it was identified that the participants experienced an increase of one to two levels. The increase of one level is from the basic to the skilled level, and the two-level increase is from beginner to skilled and from basic to advanced level.

A total of $27(77.14 \%)$ participants, who were in the beginner level at the time of pre-action, experienced an increase of two levels to the skilled level. This means that the increase occurred by $100 \%$. At the time of the post-action, there were no more participants who were at the beginner or basic levels.

From the eight $(22.86 \%)$ participants who were in the basic level at the time of pre-action, five participants experienced one level increase to the skilled level. Therefore, the increase was $62.5 \%$. Three participants increased two levels to the advanced level. This means that there was an increase of $37.5 \%$. The increase that occurred based on the results of the post-action showed that the majority of the participants' ability to translate the Qur'an was in a good category.

\section{CONCLUSION}

The research results have revealed the fact that to improve the competence of prospective teachers in translating the Qur'an, educators must always reflect on themselves and strive to improve the quality of learning and understand learning and teaching styles that can create a change in the learning process. This means that teachers must be fully aware that the learning steps taken in the current learning process have not been able to provide satisfactory results so that it is necessary to develop or compile an innovative and futuristic model. This research contributes to the development of the science of tafsir learning through strengthening Arabic language skills as an effort to improve the competence of prospective Islamic religious education teachers in understanding the sources of Islamic teachings.

It was revealed that to increase the competence of prospective Islamic Education teachers in translating the Qur'an, six stages can be taken as a critical reflection. These stages are called TARJIM, where $\mathrm{T}=$ Training, $\mathrm{A}=$ Accumulation, $\mathrm{R}=$ Reading, $\mathrm{J}=$ Joint Assessment, $\mathrm{I}=$ Improvement, $\mathrm{M}=$ Make as the stage to actualize the insights and skills from the previous stages to compile a translation product.

These six stages were developed from the Tamyiz method in improving the ability to translate the Qur'an. Therefore, TARJIM can also be called a learning method in translating the Qur'an that has exegetical nuances. In addition to being an acronym, tarjim is an Arabic word, in the form of an imperative verb, which means an order to translate. 
This has an implication that every Muslim should be able to convey the messages of the Qur'an. Therefore, for anyone who wants to have and improve the ability to translate the Qur'an, the TARJIM method is a sure solution.

\section{ACKNOWLEDGEMENT}

The authors would like to thank the Institute for Research and Community Service of the Indonesia University of Education for supporting the financing for this research. Moreover, in this case, the researcher states that in the implementation of this research, it is free from conflict of interests.

\section{REFERENCES}

Abaza. (2010). Metode tamyiz; Pintar terjemah Al Qur'an $30 \mathrm{Juz}$ dan Kitab Kuning 100 jam. Tamyiz.

Abdelaal, N. M., \& Md Rashid, S. (2015). Semantic loss in the Holy Qur'an translation with special reference to Surah Al-W aqiAAa (Chapter of the event inevitable). SAGE Open, 5(4), 2158244015605880. https://doi.org/10.1177/2158244015605880

Abdelnasser, H., Ragab, M., Mohamed, R., Mohamed, A., Farouk, B., El-Makky, N. M., \& Torki, M. (2014). Al-Bayan: An Arabic question answering system for the Holy Quran. Proceedings of the EMNLP 2014 Workshop on Arabic Natural Language Processing (ANLP), 57-64.

Afan, I. (2014). Penerjemahan ayat-ayat jihad dalam Al-Qur'an terjemahan Kementrian Agama RI (Analisis wacana). Fakultas Adab dan Humaniora UIN Syarif Hidayatullah.

Ahmadi, R. (2015). Model terjemahan Al-Qur'an tafsiriyah Ustad Muhammad Thalib. Jurnal CMES, 8(1), 57-69. https://jurnal.uns.ac.id/cmes/article/view/1162 4

Aichele, G., \& Phillips, G. A. (1995). Introduction: Exegesis, eisegesis, intergesis. Intertextuality and the Bible, 7-18.

Al-Zarqani, M. al-A. (1995). Manâhil al- 'irfân fî 'ulûm Al-Qur'ân. Dâr Al-Kitâb Al-'Araby.

Alhamuddin, A., Hamdani, F., Tandika, D., \& Adwiyah, R. (2018). Developing Al-Quran instruction model through 3A (Ajari aku AlQuran or please teach me Al-Quran) to improve students' ability in reading Al-Quran at Bandung Islamic University. International Journal of Education, 10(2), 95-100. https://doi.org/10.17509/ije.v10i2.8536

Alifuddin, M. (2012). Asbabun Nuzul dan urgensinya dalam memahami makna Qur'an. Shautut Tarbiyah, 18(1), 115-123. https://ejournal.iainkendari.ac.id/index.php/sha utut-tarbiyah/article/view/69

Alqahtani, M., \& Atwell, E. (2016). Arabic Quranic search tool based on ontology. International Conference on Applications of Natural Language to Information Systems, 478-485. https://doi.org/10.1007/978-3-319-41754-7_52

As-Safi, A. B. (2011). Translation theories: Strategies and basic theoretical issues. Al Manhal.

As-Suyuti, J. A. (2008). Al itqon fi ulumil Qur'an. Maktabah Dar Al-Fikr.

Ashim, S. A., \& Rasyid, R. F. Z. B. (2019). Teaching and learning Arabic grammars by Quranic Arabic corpus. Journal of Islam in Asia, 16(3), 1-36. https://doi.org/10.31436/jia.v16i3.833

Baihaki, E. S. (2017). Penerjemahan Al-Qur'an: Proses penerjemahan Al-Qur'an di Indonesia. Jurnal Ushuluddin, 25(1), 44-55. https://doi.org/10.24014/jush.v25i1.2339

Baihaqi, Y. (2019). Îjâz of Al-Qur'an in perspective of an Noursi and its implication towards the translation of Al-Qur'an. Jurnal Al-Bayan: Jurnal Jurusan Pendidikan Bahasa Arab, 11(2), 305-319. https://doi.org/10.24042/albayan.v11i2.4683

Baker, M. (2011). In other words: A coursebook on translation. Routledge.

Bakri, S. (2016). Asbabun nuzul: Diaog antara teks dan realita kesejarahan. At-Tibyan: Jurnal Ilmu Alqur'an Dan Tafsir, 1(1), 1-18. https://www.journal.iainlangsa.ac.id/index.php /tibyan/article/view/30

Bakry, O. (1983). Tafsir rahmat. PT. Mutiara.

Bruce, C. D., Flynn, T., \& Stagg-Peterson, S. (2011). Examining what we mean by collaboration in collaborative action research: A cross-case analysis. Educational Action Research, 19(4), 433-452. https://doi.org/10.1080/09650792.2011.625667

Chang, S. S. H. (2004). Essential tools for the new testament exegetical paper. Torch Trinity Journal, 7, 31-55. http://www.ttgst.ac.kr/upload/ttgst_resources 1 3/20123-179.pdf

Chirzin, M. (2018). Dinamika terjemah Al-Qur'an (Studi perbandingan terjemah Al-Qur'an Kemenerian Agama RI dan Muhammad Thalib). Jurnal Studi Ilmu-Ilmu Al-Qur'an Dan Hadis, 17(1), 1-24.

Creswell, J. W. (2002). Educational research: Planning, conducting, and evaluating quantitative. Prentice Hall.

Dahan, G. (2015). Thomas Aquinas: Exegesis and Hermeneutics. In P Roszak \& J. Vijgen (Eds.), Reading sacred scripture with Thomas Aquinas: Hermeneutical tools, Theological questions and new perspectives (pp. 45-70). https://doi.org/10.1484/m.tema-eb.4.000130

Dukes, K., \& Buckwalter, T. (2010). A dependency 
treebank of the Quran using traditional Arabic grammar. Proceeding of The 7th International Conference on Informatics and Systems (INFOS), 1-7.

el Fauzy, H. I. (2018). Andragogi pembelajaran Bahasa Arab metode "Tamyiz" dalam perspektif pendidikan non formal. Pembelajaran Bahasa, Sastra, dan Budaya Arab, 2, 126-139.

Farhan, F. (2017). Manajemen pembelajaran kitab kuning pola 100 jam menggunakan metode tamyiz: Penelitian di Pondok Pesantren Bayt Tamyiz Tukdana Indramayu 2017[Master's Thesis, UIN Sunan Gunung Djati Bandung]. http://digilib.uinsgd.ac.id/22940/

Fee, G. D. (2002). New Testament exegesis: A handbook for students and pastors.

Westminster John Knox Press.

Ferguson-Patrick, K. (2007). Writers develop skills through collaboration: An action research approach. Educational Action Research, 15(2), 159-180. https://doi.org/10.1080/09650790701314585

Funabiki, Y., \& Konishi, M. (2003). Long memory in song learning by zebra finches. Journal of Neuroscience, 23(17), 6928-6935. https://doi.org/10.1523/jneurosci.23-1706928.2003

Gibbs, P., Cartney, P., Wilkinson, K., Parkinson, J., Cunningham, S., James-Reynolds, C., Zoubir, T., Brown, V., Barter, P., \& Sumner, P. (2017). Literature review on the use of action research in higher education. Educational Action Research, 25(1), 3-22. https://doi.org/10.1080/09650792.2015.112404 6

Good, A. J., Russo, F. A., \& Sullivan, J. (2015). The efficacy of singing in foreign-language learning. Psychology of Music, 43(5), 627640. https://doi.org/10.1177/0305735614528833

Hakim, R. (2019). The improvement of students' competence in Islamic education programme through Tahsin Al-Quran activities. Khalifa Journal of Islamic Education, 3(1), 35-55. http://kjie.ppj.unp.ac.id/index.php/kjie/article/v iew/21

Hanafi, M. M. (2011). Problematika terjemahan AlQur'an studi pada beberapa penerbitan AlQur'an dan kasus kontemporer. Suhuf Jurnal Pengkajian Al-Qur'an Dan Budaya, 4(2), 169195. https://jurnalsuhuf.online/index.php/suhuf/artic le/view/53

Hanafiah, N., \& Suhana, C. (2009). Konsep strategi pembelajaran. Refika Aditama.

Harvey, S. A. (2010). Song and memory: Biblical women in Syriac tradition. The Père Marquette Lecture in Theology Series, 41, 9-92. https://doi.org/10.5840/pmlt2010412
Hasan, M. S. (1984). Mawrid al-ḍam'ān fí 'ulūm AlQur'ān. al-Dār al-Salafìyah.

Himam, M. W., \& Raswan, R. (2017). Tamyiz; Model alternatif pembelajaran Bahasa Arab sebagai bahasa Al-Qur'an. Lisanul'Arab: Journal of Arabic Learning and Teaching, 6(1), 18-28.

Ibrahim, N. J., Idris, M. Y. I., Yusoff, M. Y. Z. M., \& Anuar, A. (2015). The problems, issues and future challenges of automatic speech recognition for Quranic verse recitation: A review. Al-Bayan: Journal of Qur'an and Hadith Studies, 13(2), 168-196. https://doi.org/10.1163/22321969-12340024

Ikhwan, M. (2015). An Indonesian initiative to make the Qur'an down-to-earth: Muhammad Quraish Shihab and his school of Exegesis. Freie Universität Berlin.

Iqbal, M., \& Ja'far, J. (2019). Contemporary development of Qur'anic exegesis in Indonesia and Iran. Journal of Contemporary Islam and Muslim Societies, 3(1), 83-103.

Jaipal, K., \& Figg, C. (2011). Collaborative action research approaches promoting professional development for elementary school teachers. Educational Action Research, 19(1), 59-72. https://doi.org/10.1080/09650792.2011.547688

Jalaluddin bin At-Tahir, A.-A. (2008). Ahkam tajamah Al-Qur'an Al-Karim. Dar Ibn Hazm.

Jimoh, S. L. (2018). The romanization of Qur'ānic letters: An argument for a review in light of 'Ilm al-Tağwīd and modern Arabic Linguistics. Al-Bayan: Journal of Qur'an and Hadith Studies, 16(1), 44-59. https://doi.org/10.1163/22321969-12340058

Krippendorff, K. (2018). Content analysis: An introduction to its methodology. Sage publications.

Leeman, Y., van Koeven, E., \& Schaafsma, F. (2018). Inter-professional collaboration in action research. Educational Action Research, 26(1), 9-24. https://doi.org/10.1080/09650792.2017.130182 7

Mahasneh, A. A. (2018). The translation of the denotative and connotative meaning of (Sakinah) in the Holy Qur'an: An empirical study. Dirasat: Human and Social Sciences, 45(2), 303-314. https://doi.org/10.35516/0103045-002-020

Majid, N. (1995). Islam, iman dan ihsan sebagai trilogi ajaran ilahi. In B. Munawar-Rachman (Ed.), Artikel yayasan paramadina. Yayasan Paramadina.

Matin, U. A., \& Alwi, M. M. (2020). The concept of environmental corruption in the perspectives of two Qur'anic Exegesis and in the standpoint of one translation of the Qur'an in Indonesia. Proceedings of the 1st International Conference on Recent Innovations (ICRI 
2018), 2493-2501.

https://doi.org/10.5220/0009945424932501

McTaggart, R. (1996). Issues for participatory action researchers. In Z. Ortrun (Ed.), New directions in action research (pp. 243-255). Falmer.

Mukroji, M. (2014). Metode tamyiz (Sebuah formulasi teori nahwu shorof quantum). Jurnal Kependidikan, 2(1), 161-184.

Munday, J. (2016). Introducing translation studies: Theories and applications. Routledge.

Mustofa, D. (2019). Kemampuan Bahasa Arab dalam pandangan perilaku keagamaan dan kemampuan menulis Arab (Khat). Lisanan Arabiya: Jurnal Pendidikan Bahasa Arab, 3(01), 1-14. https://doi.org/10.32699/liar.v3i01.994

Newmark, P. (1988). A textbook of translation (Vol. 66). Prentice Hall.

Ocker, C. (1999). Medieval exegesis and the origin of Hermeneutics. Scottish Journal of Theology, 52(3), 328-345. https://doi.org/10.1017/s0036930600050249

Peachy, D. W. S. (2013). English translations of the Qur'an and the roles of why, by whom, for whom and how. Al-Bayan: Journal of Qur'an and Hadith Studies, 11(2), 31-54. https://doi.org/10.11136/jqh.1311.02.03

Pepinsky, H. B. (1982). Hermeneutics, exegesis, and eisegesis in remembrance of things past. The Counseling Psychologist, 10(1), 83-86. https://doi.org/10.1177/0011000082101010

Piper, J. (2013). Biblical exegesis: Discovering the meaning of scriptural texts. Desiring God.

Porter, S. E., \& Clarke, K. D. (1997). What is exegesis?: An analysis of various definitions. In S. E. Porter (Ed.), Handbook to exegesis of the new testament (pp. 3-21). Brill.

Pregill, M. (2020). The golden calf between Bible and Qur'an: Scripture, polemic, and exegesis from Late Antiquity to Islam. Oxford University Press.

Qadafy, M. Z. (2019). Qur'anic exegesis for commoners: A thematic sketch of nonacademic tafsīr works in Indonesia. Studia Islamika, 26(2), 247-276. https://doi.org/10.15408/sdi.v26i2.8144

Qassem, M. (2021). Translations of stylistic variations in the Noble Qur'an into English: Stylistic and exegetical perspectives. Journal of Intercultural Communication Research, 50(3), 304-322.

https://doi.org/10.1080/17475759.2020.184101 6

Rahman, S. A., Baharuddin, N., Ahmad, H., Sempo, M. W., Saad, N. S. M., Baharun, H., \& Muhammad, N. A. F. (2017). Levels of understanding the content of the Quran based on surah Al-Ikhlas. Advanced Science Letters, 23(5), 4619-4622. https://doi.org/10.1166/asl.2017.8945

Rippin, A. (1988). The function of asbāb al-nuzūl in Qur'ānic exegesis. Bulletin of the School of Oriental and African Studies, 51(1), 1-20. https://doi.org/10.1017/s0041977x00020188

Rohmana, J. A. (2019). Sundanese translations of the Qur'an in West Java: Characteristics and the limits of translation. DINIKA: Academic Journal of Islamic Studies, 4(2), 165-200. https://doi.org/10.22515/dinika.v4i2.1713

Sani, R. A. (2013). Inovasi pembelajaran. Bumi Aksara.

Savaskan, I. (2019). Interpersonal metadiscourse in the English translations of the Holy Quran. British Journal of Middle Eastern Studies, 48(3), 1-14. https://doi.org/10.1080/13530194.2019.162301 1

Shihab, M. Q. (1996). Membumikan Al Qur'an fungsi dan peran wahyu dalam kehidupan masyarakat. Mizan.

Somekh, B. (2010). The collaborative action research network: 30 years of agency in developing educational action research. Educational Action Research, 18(1), 103-121. https://doi.org/10.1080/09650790903484566

Stolze, R. (2012). The hermeneutical approach to translation. Vertimo Studijos, 5(5), 30-42. https://doi.org/10.15388/vertstud.2012.5.10557

Supiana, S., Badrudin, B., \& Farhan, F. (2018). Investigating tamyiz method for learning Kitab Kuning within 100 hours: An educational management perspective. Proceedings of the International Conference on Islamic Education (ICIE 2018), 261(ASSEHR), 250-255. Atlantis Press. https://www.atlantispress.com/proceedings/icie-18/25901247

Supriyadi, T., \& Julia, J. (2019). The problem of students in reading the Quran: A reflectivecritical treatment through action research. International Journal of Instruction, 12(1), 311-326. https://doi.org/10.29333/iji.2019.12121a

Supriyadi, T., Julia, J., \& Firdaus, E. (2019). The problems of gender equality: A reconstruction of Islamic doctrine. Journal of Social Studies Education Research, 10(2), 91-110. https://jsser.org/index.php/jsser/article/view/69 8

Supriyadi, T., Julia, J., \& Iswara, P. D. (2019). Phonological interference in reciting AlQur'an: A critical reflection on the learning of Al-Qur'an phonology through action research. International Journal of Learning, Teaching and Educational Research, 18(9), 46-77. https://doi.org/10.26803/ijlter.18.9.3

Supriyadi, T., Julia, J., Sobana, A., Rahminawati, N., \& Taja, N. (2020). Digital Technology era and Al-Quran understanding problem: Critical reflection of Al-Quran Learning through action 
research. Journal of Advanced Research in Dynamical \& Control Systems, 12(6), 23842401.

https://doi.org/10.5373/JARDCS/V12I6/S2020 1198

Williams, J. G. (1973). Exegesis-eisegesis: Is there a difference? Theology Today, 30(3), 218-227. https://doi.org/10.1177/004057367303000302
Woodward, M. R. (1993). Textual exegesis as social commentary: Religious, social, and political meanings of Indonesian translations of Arabic hadith texts. The Journal of Asian Studies, 52(3), 565-583.

https://doi.org/10.2307/2058854 